\title{
What Do IT-People Know about the Nordic History of Computers and User Interfaces?
}

\author{
A Preliminary Survey
}

\author{
Anker Helms Jørgensen \\ IT University of Copenhagen, DK-2300 Copenhagen S Denmark \\ anker@itu.dk
}

\begin{abstract}
This paper reports a preliminary, empirical exploration of what ITpeople know about the history of computers and user interfaces. The principal motivation for the study is that the younger generations such as students in IT seem to know very little about these topics. The study employed a free association method administered as email. Eight students and four researchers participated, between 26-34 and 48-64 years of age, respectively. Responses totaled 222 and we analyzed and categorized them. First, the Nordic touch was extremely limited. Secondly, the knowledge of both students and researchers seems heavily based on personal experience so that the researchers know much more about the earlier days of computing and interfaces. Thirdly, there is a tendency amongst the students to conceptualize the history of computers in interface features and concepts. Hence, the interface seems to become the designation or even the icon for the computer. In other words, one of the key focal points in the area of human-computer interaction: to make the computer as such invisible seems to have been successful.
\end{abstract}

Keywords: User interface history, computer history, knowledge.

\section{Exploring User Interface History}

In the last years, I have become interested in the history of user interfaces to computers $[4,5]$. My motivation is primarily the scarcity of the literature on this topic and a strong impression that young IT-people know very little about the history of user interfaces - and apparently also about the history of computers. They seem to believe that the PC was the first computer and that Windows was the first user interface. My exploration of the history of user interfaces is fascinating, and being a newcomer with a background in computer science and human-computer interaction (HCI), I have to adopt historians' practices and discourses [3].

The target audience for my research in user interface history consists of three main segments: historians of technology, researchers in IT and HCI, and students of IT and HCI. In accordance with good practice in HCI - know thy user - I would like to know more about the target audience. Getting to know the historians' practice and discourse 
takes place through networking and studies of the literature. I do know IT-researchers and IT-students quite well in general, but my understanding of their knowledge of the history of computers and interfaces is rudimentary. Therefore, I conducted an exploratory survey of what the two groups know about these topics. This will help me sharpen my research questions and communicate my results more succinctly.

\section{Probing Researchers' and Students' Knowledge}

Given the nature of this unchartered territory, I included the broader history of computers in order to contextualize the interface issue. As computing is an international phenomenon I decided only to address the Nordic touch implicitly. I employed an open-ended data collection method: free associations. In addition, I recruited informants in my immediate vicinity. The researchers were four colleagues: two university researchers and two from industry with considerable research experience. They were all computer scientists and knowledgeable or experts in HCI, between 48 and 64 years of age. I recruited the students among the ones I supervised at the master level at the IT University in the fall of 2006. I asked fourteen students and received eight answers. Their median study time at the IT University was 1.5 years. They all had a baccalaureate degree in various areas, including media technology, IT-studies, and Danish. Their age varied between 26 and 34 years. The specific wording of the free association task was as follows.

Please complete a brief, free association task on the following question:

When I say the history of computers, what do you say?

Write down 5-10 points, names, events, systems, paradigms, etc.

There was a similar question on the interface. I administered the survey by email. The respondents returned 222 answers, on average 28 for the researchers and 14 for the students, about equally distributed between computer and interface history. The respondents spent between 10-15 minutes and one hour in responding. One respondent in each group returned a 1-page essay, while the remaining respondents returned a list of words or short statements. The lengthy responses were condensed. I categorized all answers twice, with several weeks between to achieve some robustness (inter-rater reliability over time), in categories derived from the data that reflect major historical aspects. The Appendix lists all the responses in abbreviated form, enabling the reader to get an impression of the breadth and diversity of the material.

\section{What Do They Know?}

A summary of the results appears in Table 1. In the following, I present and discuss the three most noteworthy trends.

The numbers are absolute because of the almost equal number of responses in the four groups. Note that I scored the two last rows independently of the rows above. 
Table 1. Responses in categories listed alphabetically, blank cells denote no response

\begin{tabular}{|c|c|c|c|c|}
\hline \multirow[b]{2}{*}{ Category } & \multicolumn{2}{|c|}{$\begin{array}{c}\text { The History of } \\
\text { the Computer }\end{array}$} & \multicolumn{2}{|c|}{$\begin{array}{c}\text { The History of } \\
\text { the User Interface }\end{array}$} \\
\hline & Researchers & Students & Researchers & Students \\
\hline Applications & 3 & & 3 & 1 \\
\hline Games & & 3 & & \\
\hline Evolution & 6 & 7 & 3 & 3 \\
\hline Internet & 1 & 3 & 1 & 2 \\
\hline Miscellaneous & 4 & 1 & 2 & 1 \\
\hline Organizations & 1 & 5 & & 1 \\
\hline $\begin{array}{l}\text { Personal } \\
\text { computer }\end{array}$ & 5 & 18 & 2 & 1 \\
\hline Pioneers & 6 & 1 & 3 & 1 \\
\hline Research & & & 7 & \\
\hline Society & 2 & 2 & & \\
\hline Software & 8 & 3 & & 6 \\
\hline Technology & 11 & 5 & 4 & 2 \\
\hline Use \& User & 3 & 1 & 6 & 2 \\
\hline User Interface & 4 & 11 & 27 & 30 \\
\hline Total & 54 & 60 & 58 & 50 \\
\hline Nordic & & 2 & 1 & 1 \\
\hline Pre-pc & 36 & 7 & 23 & 9 \\
\hline
\end{tabular}

Firstly, the Nordic touch is modest, in fact only four responses out of $222(1.8 \%)$, as seen in the second-to-last row. The responses were:

o The Danish PC Piccoline manufactured by Regnecentralen from 1984 to 1989

o The Danish Computer Fair in Copenhagen

○ A user interface development method by the Danish researcher Søren Lauesen

o Jakob Nielsen's alertbox at www.useit.com

These examples do not lend support to a strong Nordic anchoring as the Computer Fair was probably much like computer fairs in other countries and Jakob Nielsen is indeed Danish but has been living in the United States for several decades ${ }^{1}$. The limited Nordic touch is in line with the decline of the Nordic IT industry in the last decades. Thus, in Denmark, the best-known IT-company Regnecentralen closed in 1992 after two decades of organizational and financial turbulence [6]. Hence, it seems that knowledge of computer and user interface history is strongly internationally grounded.

Secondly, there is a marked difference in the responses in the two groups regarding the user interface. Consider first the following student response: Machintosh ${ }^{2}$, Xerox Parc, GUI, Window metaphor, Desktop metaphor, Microsoft, DOS. Note that the first five of these seven items are canonical user interface concepts. Is this a response to the history of computers or to the history of user interfaces? It is the former, in fact. This student was extreme, but student responses on user interfaces to the question on

\footnotetext{
${ }^{1}$ In fact, students often ask me if he is Danish or American.

${ }^{2}$ Spelling error in original response.
} 
computer history were much more frequent than researcher responses (11 versus 4 ). Hence, students seem to associate computer history much more strongly to the user interface than researchers. This trend is in line with a recent terminological shift towards use of the term user interface at the expense of the term computer. An example from a recent $\mathrm{Ph} . \mathrm{D}$. thesis is, "We become part of the interface or rather we bring the interface with us everywhere, we create practices around the interface" [1, p. 88]. Contrasting this, it is interesting to note that the students have far fewer answers in the category use and user (3 versus 9), perhaps because students are brought up with computers and therefore consider user-trouble an inherent and inevitable part of the game?

Thirdly, there is a very marked difference between the researchers and the students regarding the emphasis on personal computers in the history of computers. Here the students' responses are almost four times more frequent than the researchers' (18 versus 5). This trend is supported by looking at pre-PC responses in the bottom row. Only 7 and 9 of the students' responses are pre-PC, while the corresponding figures for the researchers are 36 and 23 . Hence, there is strong evidence that the students seem to associate computer history with the PC era. Given that in the last two decades or so with client-server architecture, access to mainframe computers happens through PCs and not through "dumb" terminals, it is not surprising that students have little clues about large computers, let alone about their origin. Nevertheless, modern computer users are using more computers and more powerful computers than ever before. Surfing on the internet means using myriads of small and large computers, networks, and protocols - yet the computers are largely invisible. The interface appears to connect the user to other users and the vast amount of information and services. The technology itself has become hidden while the interface has come to the fore [4]. Hence, one of the key focal points in the area of human-computer interaction: to make invisible the computer as such seems to come closer to realization.

\section{Conclusion}

First, the Nordic touch was extremely limited as only four of 222 responses addressed the Nordic aspects. Secondly, the knowledge of both students and researchers seems heavily based on personal experience so that the researchers know much more about the earlier days of computing and interfaces. Hence, this study suggests that historical knowledge on computers and user interfaces is relative and associated with generation-specific personal experiences. Thirdly, there is a tendency amongst the students to conceptualize the history of computers in interface features and concepts. Hence, the interface seems to become the designation or even icon for the computer. We should interpret these conclusions with considerable caution due to the very small sample of IT-people recruited in my work context and the open-ended data collection method. The study is an indication of the lie of the land and may serve as a point of departure for future work.

After the study, an interesting twist emerged. It turned out that three of the four researchers did not know about the changing meaning of the term computer in the 1940s-from denoting a person doing calculations manually to denoting a digital calculation device [2] nor did several of them know that many of the first programmers were women. Indeed, this is a strong illustration of the above-mentioned generation-specific and experience-based knowledge of computer and user interface history. 


\section{References}

[1] Christensen, M.S.: As We May Feel - Interpreting the Culture of Emerging Personal Affective Mobile Media. Ph.D. Thesis, IT University of Copenhagen (2006)

[2] Grier, D.A.: When computers were human. Princeton University Press, Princeton (2005)

[3] Jørgensen, A.H.: Exploring the History of User Interfaces: The Myth of Xerox Parc and Other Oddities. In: Proc. 6th Danish HCI Research Symposium, Aarhus, November 15, pp. 29-30 (2006)

[4] Jørgensen, A.H., Udsen, L.E.: From calculation to culture - A brief history of the computer as interface. In: Jensen, K.B. (ed.) Interface://Culture - the World Wide Web as a political resource and aesthetic form, Samfundslitteratur, pp. 39-64 (2005)

[5] Jørgensen, A.H., Myers, B.A.: User Interface History. In: Proc. CHI 2008 extended abstracts on Human factors in computing systems, pp. 2415-2418. ACM, New York (2008)

[6] Thorhauge, C.: Tidslinie over RC's historie [Timeline on the History of RC]. In: Isaksson, H., Pedersen, O. (eds.) Regnecentralen - Dansk Institut for Matematikmaskiner, Festskrift ved 50 året for oprettelsen, 12. oktober 1955. Dansk Datahistorisk Forening (2005) 


\section{Appendix}

The 222 responses appear below in alphabetical order. They are organized according to Computer History Researchers, Computer History Students, Interface History Researchers, and Interface History Students. The original responses have been condensed in many cases while preserving the gist of the response.

\section{Computer History Researchers}

2. 3. 4. and 5. generation programming languages administrative systems

Alan Turing

Alan Turing

Alan Turing

Apple II

Basic

Citizens required to use IT

Compilers for high-level

$$
\text { languages }
$$

\section{DOS}

Edsac/Eniac

Eniac

ferrite core

few and privilied users to everyone everywhere

\section{Fortran}

Hopeless operational procedures in embedded software, eg in DVD players

Hype and sales talk

IBM

IBM 3270

IBM pc

IBM $/ 360$

IBM OS/360

IBMs waterfall model

Internet

John von Neuman

John von Neuman

levels in systems and architectures

Macintosh

mainframe - mini - micro

computers

mainframes

mainframes

microcomputers

Microsoft overtook IBM on

the pc market

minicomputers

numerical calculations

operating systems

$\mathrm{pc}$

$\mathrm{pc}$

$\mathrm{pc} / \mathrm{Mac}$

pc-revolution

PDAs

process control

punched cards

punched cards

smaller and smaller specialist to routine tasks

for ordinary users

superstition and

incompetent support

system development

the computer: an everyday

appliance

ubiquitous comp.

Univac

user trouble

vacuum tubes to transistors

Vannevar Bush

\section{Computer History Students}

Alan Kay

Amiga 500

Apple

Arpanet

Atari, Commodore 64

Commodore 64 game

console

Commodore 64 games

Commodore 64

programming

Commodore 64 tv and casette tape

Computer Fair in Bella

Center

Computer technology: IO

to silicone chips etc

Desktop-metaphor

Diskette development from

8" til 3.5" to CD etc

Displays: from large and

clumsy to flat, less bulky

DOS

DOS: this weird, impoverished place

Ethernet

Game consoles: Amiga,

Sega, Nintendo

GUI

HTML - opened up with

Flash etc - had not

happened since LEGO

IBM

IBM

IBM

Internet - the computer

becomes much more

interesting

large computers

Machintosh

Macintosh: the first that my dad had in his office matrix printer

Microsoft

Microsoft Bill Gates

miniaturization

mainframe, PC, PDA,

portable, desktop

computer etc.

miniaturize one computer

for many users - one

computer for one user

my first portable: an IBM

Thinkpad

one user uses many

computers: portable,

PDA, cell phone, ...

operating systems like

OS/2 and Windows'

pc

pc 286

pc 386

pc 486

pc 486 Windows 3.1

pc AT

pc IBM PC my mom used

WordPerfect

pc Pentium

pc Pentium 2/3/4

pc XT

Piccoline

portable - a cool invention

portable in backpack, as

you go

printer development:

Matrix/9-24 til ink/laser

printers

punch cards

the computer invented in the USA, applied in the military

the first computer was as

large as a room

the first computers were as large as a room

the desktop computer becoming prevalent in a few

years

time sharing

Unix

window metaphor

Xerox

Xerox PARC

Xerox PARC

User Interface History

Researchers 


\author{
"terminal" \\ 3-D animation \\ Adobe \\ Alan Kay \\ Apple II \\ Ben Shneiderman \\ $\mathrm{CHI}$ conferences, \\ especially in 1984 \\ Command dialogue \\ Command doialogue still \\ thrives in Linux \\ Control panels with \\ switches by the hundred \\ Convergence between \\ word-processing and \\ desk-top publishing \\ CUA standard \\ Direct Manipulation \\ Displays \\ Displays \\ Donald Norman \\ Donals Norman's book \\ Psychology of Everyday \\ Things \\ DOS on the microcomputer \\ Function keys in \\ WordPerfect \& Word \\ Gould \& Lewis paper in \\ Comm. ACM 1985 \\ "Designing for \\ Usability..." \\ Graphics in process control \\ applications \\ GUI \\ GUI \\ homepages still only made \\ by freaks \\ HTML metafor differs \\ from GUI metafor \\ IBM 3270 \\ IBM 3270 \\ Internettet \\ Jakob Nielsen's Alertbox \\ Jef Raskin's Apple II user \\ manuals \\ Jef Raskin's work on the \\ Macintosh \\ John Seeley Brown's \\ keynote at CHI '83 \\ Macintosh \\ Microsoft's Office-suite \\ Online access, not only \\ specialists \\ Patricia Wright's FLUID \\ model \\ Punch card/tape as input, \\ print/batch as output \\ punch tape
}

\author{
scripts - a kind of \\ command language \\ switches \\ teletype \\ teletypes \\ the Mouse \\ the mouse \\ the mouse \\ the user as factor \\ thinking aloud test \\ typewriter \\ user frustrations \\ walk-up-and-use need \\ web not applicable to GUI \\ interfaces, but is being \\ used anyway \\ websites: surf to another if \\ it doesn't work \\ wide application of home \\ computers because of the \\ graphical user interface \\ WIMP: Windows, Icons, \\ Menus and Pointing \\ Devices \\ Windows, especially \\ Windows'95 \\ WYSIWYG: What You \\ See Is What You Get \\ Xerox PARC \\ Xerox Star
}

User Interface History

$\underline{\text { Students }}$

Accessibility

Apple

Apple II

Browsers: Netscape, Explorer

Cognitive load

Colour displays

Command dialogue to graphics

Desktop metaphor

Desktop metaphor

DOS

DOS

Double click: learning problems

Douglas Engelbart: As We

Graphics vs. codes, easier

for ordinary users

GUI and not UI

HTML: decide appearance yourself
IBM PC used by my mom, blue-white, cursor block

Iconic user interfaces

Icons

Intuition: my two-year old nephew could swith Windows XP on and off

Joystick, not keyboard on C64 game console

LINUX

LINUX: various Linux distros

Macintosh

Microsoft

Microsoft made the use of computers increase early 1980 s

Mobile devices

Operating systems

OS X

Piccoline - graphic interface

Software on mobile devices

Text-based - DOS Piccolone

Text-based interaction

User Interface \& usability focus today vs. 1980s

User Interface term invented by tech people hard, interface better

User Interface: engineering paradigm - before the human aspect

Virtual Windows by Søren Lauesen

WIMP: Windows, Icons, Menus, Pointing devices

Windows 2000

Windows 3.1 lack of consistency

Windows 3.11

Windows 95

Windows 98

Windows ME

Windows various versions

Windows various versions

Windows XP

Word

WordPerfect's commands WWW 